\title{
DAS PRÁTICAS CONCORRENCIAIS ILÍCITAS: AS DIFERENÇAS ENTRE CONCORRÊNCIA DESLEAL E INFRAÇÃO À ORDEM ECONÔMICA
}

\section{OF THE ILLICIT COMPETITIVE PRACTICES: DIFFERENCES BETWEEN UNFAIR COMPETITION AND THE VIOLATION OF ECONOMIC ORDER}

\author{
Simone Letícia Severo e Sousa
}

Doutora em Direito Público pela Pontifícia Universidade Católica de Minas Gerais. Coordenadora do curso de Direito e do Curso de pós-graduação "Novas tendências do Direito Civil e do Direito Processual Civil" da Universidade José do Rosário Vellano - Unifenas/BH. Professora universitária.

E-mail: simoneleticia77@gmail.com

Recebido em: 12/02/2016

Aprovado em: 03/05/2016

Doi: $10.5585 / \mathrm{rdb} . v 14 \mathrm{i} 6.349$

\begin{abstract}
RESUMO: As diferenças entre infração à Ordem Econômica e concorrência desleal devem ser esclarecidas com base em princípios e regimes peculiares. O Direito repudia duas formas de concorrência: a concorrência desleal e a utilizada com o abuso de poder. Perceber-se-á que há dúvidas acerca de tais conceitos e compete à doutrina esclarecer tais questões, uma vez que as obras de Direito Econômico e Direito Empresarial tratam do assunto de forma incidental, sem a profundidade merecida. Há que ressaltar que a concorrência desleal é reprimida nas searas civil e penal envolvendo apenas os interesses particulares dos empresários concorrentes; enquanto a concorrência que envolve abuso de poder é reprimida também na seara administrativa, compromete as estruturas de livre mercado e é denominada de infração da Ordem Econômica. A concorrência desleal se diferencia substancialmente da infração da Ordem Econômica, principalmente levando-se em conta que as lesões produzidas pela concorrência desleal não alcançam outros interesses além dos do empresário vitimado pela prática irregular.
\end{abstract}

Palavras-Chave: Atividade Econômica. Concorrência Desleal. Infração à Ordem Econômica.

\begin{abstract}
The differences between the violation of the economic order and unfair competition must be clarified on the basis of principles and peculiar regimes. The law rejects two forms of competition: unfair competition and the use of abuse of power. It will be realized that there are doubts about such concepts and it's the doctrine responsibility to clarify these issues, since the works of Economic Law and Business Law address the issue indirectly, without the deserved depth. It must be emphasized that unfair competition is suppressed in civil and criminal crops involving only the private interests of competing entrepreneurs; while competition involving abuse of power is also repressed in administrative harvest, compromises the free market structures and is called a violation of economic order. Unfair competition differs substantially from the violation of the economic order, particularly bearing in mind that the lesions produced by unfair competition does not reach other interests than those of businessman victim of malpractice.
\end{abstract}

Keywords: Economic Activity. Unfair Competition. Violation of Economic Order. 
SUMÁRIO: Introdução; 1. Conceito de concorrência; 2. Conceito de ordem econômica; 3. A comparação entre concorrência desleal e infração à ordem econômica; Conclusão; Referências.

\section{INTRODUÇÃO}

A Ordem Econômica adotada pela Constituição Federal é típica do sistema econômico com um regime peculiar. Esse regime pode ser nomeado como neoliberal. Assim, o modelo econômico definido na Constituição Brasileira se funda na livre iniciativa, mas consagra também outros valores compatíveis com a mesma.

Seguindo a linha sistemática do art. 170 da Constituição Federal, para o desenvolvimento econômico, é fundamental o princípio da concorrência. A concorrência é essencial para o desempenho econômico, pois consiste na disputa entre todas as empresas para conseguir um maior e um melhor espaço no mercado.

Afinal, é através da livre concorrência que as empresas melhoram suas condições de competitividade e são forçadas a aprimorar sua tecnologia, qualidade e custos, oferecendo assim, condições mais favoráveis ao consumidor, funcionando como uma mola propulsora da economia de mercado.

Destarte, o objetivo maior é demonstrar as diferenças entre concorrência desleal da infração da Ordem Econômica, principalmente levando-se em conta que as lesões produzidas pela concorrência desleal não alcançam outros interesses além dos do empresário vitimado pela prática irregular.

Em razão das diferenças entre concorrência desleal e infração da Ordem Econômica, deve-se observar que a legislação não se preocupou em estabelecer mecanismos de repressão administrativa, contentando-se com as repressões civil e penal.

É premente a necessidade do estudo da concorrência sob o aspecto público e privado, ressaltando o princípio constitucional da livre concorrência que impõe uma diretriz geral a orientar todas as ações dos poderes públicos.

Salientar-se-á, também, que a legislação de defesa da concorrência prevista na Lei 9.279/96 tutela o agente econômico, na ótica da tutela privada, assegurando também o ambiente concorrencial.

A Lei n. 12.529 de 2011, por sua vez, estrutura o Sistema Brasileiro de Defesa da Concorrência - SBDC e dispõe sobre a prevenção e a repressão às infrações contra a ordem econômica, orientada pelos ditames constitucionais de liberdade de iniciativa, livre concorrência, função social da propriedade, defesa dos consumidores e repressão ao abuso do poder econômico.

\section{CONCEITO DE CONCORRENCIA}

Ao tratar da concorrência preleciona João Bosco Leopoldino da Fonseca: surge no final do século XIX o modelo intervencionista que dominará todo o século XX, assumindo o Estado a responsabilidade de conduzir o desenrolar do processo econômico e de realizar novas formas de atuação. (FONSECA, 2008, p. 28)

Com a concentração do poder econômico nas mãos de tão poucos foi necessária a intervenção do Estado, salvaguardando a liberdade de iniciativa e garantindo de forma mais a liberdade econômica das empresas.

E complementa Daniel Firmato de Almeida Glória: assim, a exploração direta da atividade econômica pelo Estado constitui-se numa exceção. A regra é a de que o estado não deve atuar diretamente no domínio econômico. A exceção está restrita à necessidade decorrente de 
dois fatores determinantes: imperativas de segurança nacional e relevante interesse coletivo. (GLÓRIA, 2003, p. 54)

Assim demonstra Farjat: neste contexto econômico é que o direito da concorrência, núcleo do direito econômico contemporâneo, assume ares de importância, transformando o Direito Econômico de um direito da Intervenção do Estado para um instrumento de defesa dos direitos do cidadão e das liberdades fundamentais previstas na Constituição. (farjat, 1996, p.19)

E de acordo com João Bosco Leopoldino da Fonseca: a política de proteção da concorrência é vista como uma forma de garantir o equilíbrio do Mercado, Mercado baseado na livre iniciativa, sendo por isso mesmo o mais dinâmico e o produtivo dos sistemas econômicos, mas pelo mesmo motivo, é aquele que tende inevitavelmente a apresentar um nível crescente de concentração de capital, sendo imperiosa a regulação deste Mercado, o que é feito pelo Direito de Concorrência. (FONSECA, 2008, p. 8)

Segundo Henry Campbell Black: concorrência é a disputa entre dois rivais. É a luta entre dois rivais pelo mesmo negócio ao mesmo tempo; é a procura ou esforço para ganhar o que o outro está se esforçando para ganhar ao mesmo tempo. (BLACK, 1979, p. 279)

Para Benjamin M. Shieber: concorrência ou competição no campo econômico consiste na luta entre diversas empresas para conseguir maior penetração no mercado, quando se fala de vendedores, ou uma maior ou melhor parte da oferta, quando se fala em compradores. É essa luta que a lei antitruste tenciona proteger e amparar, e que já foi objeto de cuidados por parte de muitos dos países do mundo. (SHIEBER, 1996, p. 61)

Ensina Isabel Vaz que a ação tradicional de concorrência pressupõe uma ação desenvolvida por um grande número de competidores, atuando livremente no Mercado de um mesmo produto, de maneira que a oferta e a procura provenham de compradores ou de vendedores cuja igualdade de condições os impeça de influir, de modo permanente ou duradouro, no preço dos bens e serviços. (VAZ, 1993, p. 27)

Conforme os ensinamentos de Werter Faria: o direito de concorrência engloba o conjunto de regras que têm por objeto a intervenção do estado na vida econômica para garantir que a competição das empresas no mercado não seja falseada por meio de práticas colusórias ou abusivas. (FARIA, 1992, p. 07)

Ademais, a concorrência não é um fim em si mesmo, mas um meio pelo qual se busca criar uma economia mais eficiente.

Nesse contexto, diz Gesner Oliveira: a defesa da concorrência não virá naturalmente como uma preocupação posterior à liberalização, mas como um de seus elementos catalisadores, sem o qual se torna difícil a integração no plano internacional. (OLIVEIRA, 2001, p. 02)

Em uma economia eficiente, há uma maior variedade de produtos pelos menores preços e os cidadãos desfrutam de um nível máximo de bem-estar econômico. Assim, a finalidade da concorrência é tornar máximo o nível de bem-estar econômico da sociedade.

Carlos Barbieri Filho, por sua vez, assim define concorrência: concorrência é disputar, em condições de igualdade, cada espaço com objetivos lícitos e compatíveis com as aspirações nacionais. Consiste no setor econômico, na disputa entre todas as empresas para conseguir maior e melhor espaço no mercado. (BARBIERI FILHO, 1984, p. 119)

Sendo assim, a economia competitiva é também uma condição necessária para o desenvolvimento a longo prazo, uma vez que, nesse ambiente econômico, as empresas deparamse com incentivos adequados para aumentar a produtividade e introduzir novos e melhores produtos no mercado, gerando assim o crescimento econômico.

\section{CONCEITO DE ORDEM ECONÔMICA}


O regime da concorrência é propício ao ambiente da livre iniciativa, que implica a liberdade de todos se apropriarem dos meios de produção e desenvolver atividade econômica, conforme o disposto no art. 170 da Constituição Federal.

À luz da Constituição Brasileira, a Ordem Econômica funda-se, essencialmente, na atuação espontânea do mercado. Entretanto, o Estado pode intervir para implementar políticas públicas, corrigir distorções e, sobretudo, para assegurar a livre iniciativa e promover seu aprimoramento. Exige-se, pois, a ação Estatal para a reorganização da livre iniciativa e livre concorrência, ainda que se trate de hipótese excepcional.

Desse modo, a livre concorrência é um dos princípios que norteia a ordem econômica brasileira (art. 170, IV, da Constituição Federal de 1988), visando garantir aos agentes econômicos a oportunidade de competição no mercado de forma justa, livre de práticas abusivas do poder econômico. Portanto, a livre concorrência funciona como uma mola propulsora para que as empresas a busquem sempre o aperfeiçoamento, tentando reduzir os custos, bem como aumentar a produtividade e a qualidade da sua produção.

O princípio da livre concorrência é o corolário direto da liberdade de iniciativa, expressando a opção pela economia de mercado e os princípios-fim (dispostos no art. 170/CF) delineiam os objetivos que a Ordem Econômica deverá atingir.

No Brasil, as agências reguladoras têm atribuição legal de promover a livre concorrência no exercício de suas funções regulatórias e tal competência é exercida via de regra por meio da análise dos efeitos das normas regulatórias editadas pelas agências sobre a concorrência nos mercados regulados, bem como por meio do monitoramento dos comportamentos dos agentes regulados que detêm posição dominante, com vistas prevenção regulatória de seu exercício abusivo.(PEDRA, 2012, p. 05)

No Estado de Direito, a Ordem Econômica é protegida pela Constituição e pelas leis, tanto contra as manobras dos particulares quanto do próprio Estado.

Ordem Econômica é a expressão de um certo arranjo econômico, dentro de um específico sistema econômico, preordenado juridicamente. É a sua estrutura ordenadora, composta por um conjunto de elementos que conforma um sistema econômico. (TAVARES, 2003, p. 87)

Assim, o equilíbrio da Ordem Econômica é fundamental, sendo poder-dever do Estado garantí-lo. E a concorrência é um instrumento, para "assegurar a todos, existência digna, conforme os ditames da justiça social".

João Bosco Leopoldino da Fonseca define Ordem Econômica como aquele conjunto estabelecido pela Constituição e que tem por objetivo fixar parâmetros da atividade econômica, coordenando a atuação dos diversos sujeitos que põe em prática aquela mesma atividade. (FONSECA, 1995, p. 86)

Nota-se que o Direito Econômico procura estabelecer regras em conformidade com a realidade, tomando as relações jurídico-econômicas, quer entre particulares, quer entre estes e o Estado. Nesse diapasão diz Washington Peluso Albino de Souza: também podemos conceituar a Ordem Econômica a partir da idéia de um conjunto de princípios que, funcionando harmoniosamente, oferecem-nos tanto a concepção de "sistema econômico", como a de "regime econômico". O primeiro seria a concepção teórica, o "modelo econômico" idealizado, o "tipo ideal", enquanto que o segundo já se afirma como traduzindo a realidade da vida econômica. (SOUZA, 1994, p. 140)

Convém ressaltar, pois, que a Ordem Econômica, nos termos do art. 170 da Constituição Federal, é regrada pelos princípios da livre concorrência, da função social da propriedade e da defesa do consumidor, não sendo admitido qualquer tipo de infração.

A Ordem Econômica adotada pela Constituição Federal é típica do sistema econômico com um regime peculiar. Esse regime pode ser nomeado como neoliberal. Assim, o modelo 
econômico definido na Constituição Brasileira se funda na livre iniciativa, mas consagra também outros valores compatíveis com a mesma.

A livre iniciativa é uma manifestação do liberalismo, uma vez que prioriza a liberdade e a igualdade, consagrando a própria liberdade diante das restrições impostas pelo Estado.

Ademais, só pode existir a livre concorrência onde há livre iniciativa; porém, pode existir livre iniciativa sem livre concorrência. E é através da livre concorrência que os consumidores terão produtos de qualidade e preços justos.

Claro está que essa competitividade deveria ser de forma sadia. No entanto, há as distorções de mercado, tanto que a livre concorrência não é somente aquela que se cria espontaneamente no mercado, mas também aquela derivada das normas da política econômica vigente.

Há que se observar que a livre concorrência só é alcançada quando os poderes públicos estão dispostos a preservá-la e também quando desejam o seu florescimento.

\section{A COMPARAÇÃO ENTRE CONCORRÊNCIA DESLEAL E INFRAÇÃO À ORDEM ECONÔMICA}

O aumento da competição e dos conflitos por acesso a mercados e a oportunidades na economia internacional indica como os diversos atores - jogadores dos tabuleiros das finanças e da produção e comércio de bens - estão inseridos num mercado globalizado, onde o tempo pode ser contado em frações de segundo e ganhos ou perdas são computados em bilhões.

Percebe-se, de maneira clara, que a concorrência, mesmo que corretamente exercida pelos competidores, não deixa de imprimir prejuízo a um deles ou, se houver pluralidade de opositores, a vários. Mas cuida-se de prejuízo que se origina de concorrência lícita, quer dizer, daquela desenvolvida dentro das regras econômico-jurídicas de competição de mercado; daí por que não encontra a obrigação de ressarcimento da parte de qualquer particular - ainda que envolvido diretamente na disputa - ou do Poder Público. (LOPES, 2002, p. 28/29)

A proteção da concorrência ocorre pelas normas de propriedade industrial, pelas limitações à autonomia privada ou pela sanção de práticas unilaterais.

A concorrência é objeto de análise sob dois aspectos: o individual e o institucional. $\mathrm{O}$ tratamento da concorrência sob a ótica institucional implica no estudo de práticas que se voltam contra a livre iniciativa e a livre concorrência, ou seja, infrações da Ordem Econômica e condutas que atentam contra as estruturas de mercado. Institucionalmente, o estudo da concorrência é permeado por conceitos colhidos no Direito Econômico, sem que isto o retire do âmbito mercantil. Diversamente, a concorrência sob o prisma individual envolve questões que dizem respeito à atividade empresarial diretamente desenvolvida pelos competidores, com relação à clientela e à propriedade industrial, encontrando respaldo no direito privado e, inclusive, no direito penal. (PEREIRA, 2001, p. 8)

Ressalte-se que a proteção institucional da concorrência é regulada pela Lei de Defesa da Concorrência (antiga Lei 8.884/94 e atual Lei 12.529/2011 - que estrutura o Sistema Brasileiro de Defesa da Concorrência e dispõe sobre a prevenção e repressão às infrações contra a ordem econômica), enquanto a proteção individual da concorrência é regulada pela Lei de Propriedade Industrial (Lei 9.279/96), que contém normas penais repressoras; e ainda o art. 186 do Código Civil.

Desse modo, quando um empreendedor desrespeita as regras de captação de clientela, regras essas estabelecidas pelos próprios concorrentes no mercado, ter-se-á a concorrência desleal. Por outro lado, não configuram atos de concorrência desleal aqueles que o comerciante realiza no intuito de conquistar reputação de seus negócios e nem tão pouco as expressões

Revista de Direito Brasileira | São Paulo, SP | v. 14 | n. 6 | p. 215 - 230 | maio/ago. 2016 
extremamente elogiosas utilizadas pelo mesmo. Um comerciante pode publicar que é o melhor especialista da sua categoria, desde que generalize, sem precisar dizer que é melhor que o concorrente $\mathrm{X}$, designando-o expressamente ou de claro modo.

Os aspectos mais comuns da concorrência desleal são a aproximação dos estabelecimentos, a aproximação entre os estabelecimentos e produtos ou vice-versa, visando sempre a tirar vantagens dos produtos ou dos estabelecimentos conhecidos, mercê de uma concorrência ilícita. É evidente que os concorrentes desleais procuram sempre o caminho mais rápido para atingir os seus objetivos, qual seja, se aproximar de tal maneira do produto ou do estabelecimento conhecido, que fatalmente levará os menos avisados a erro e confusão, pensando tratar-se de produtos da mesma origem ou que tenham ligações diretas ou indiretas entre os estabelecimentos. (SOARES, 1980, p. 7)

Para a materialização da concorrência desleal no caso concreto, mister se faz a identificação de determinados elementos que norteiam a existência do próprio instituto e reduzem o seu campo de incidência: a) desnecessidade de dolo ou de fraude, bastando a culpa do agente; b) desnecessidade de verificação de dano em concreto; c) necessidade de existência de colisão; d) necessidade de existência de clientela; e) ato ou procedimento suscetível de repreensão. $\mathrm{Na}$ concretização da concorrência desleal, o ato ou procedimento de concorrência deve destacar-se das práticas normais dos negócios. Há de ser qualificado por ausência ou por desrespeito a preceitos de direito ou de moral" (BITTAR, 2005, p.47 e 49).

Ressalte-se que a concorrência desleal deve ser combatida não apenas pelos concorrentes lesados, mas por toda a sociedade. Entretanto, a princípio é preciso garantir a existência da concorrência, impedindo a formação de posições dominantes e em seguida deve preocupar-se com a sua lealdade.

Carlos Leduar Lopes ainda ressalta o bem jurídico protegido na concorrência desleal: a verdade é que, já na doutrina estrangeira, já na nacional, sempre com reflexos na jurisprudência, a disputa se circunscreve, via de regra, à azienda, ou ao aviamento, à clientela ou, então, a um direito inalienável do empreendedor econômico à lealdade da concorrência, com vistas a lhe ser assegurada a possibilidade de ganho no exercício dela, traduzindo desse modo, um especial direito da personalidade. A azienda não é o bem jurídico protegido pelas legislações. Isso, entre outros motivos, porque: a) se fosse um bem, a própria concorrência lícita não existiria, porque esta também causa dano à azienda; b) não poderia ser tutelado contra a concorrência desleal o empreendimento despido, por qualquer circunstância de azienda. O aviamento e a clientela igualmente não podem, cada qual a seu turno, constituir o bem jurídico assegurado contra a concorrência desleal, uma vez que não passam de particulares qualidades da azienda e, por conseguinte, não contam com a autonomia indispensável para tanto. De mais a mais, a clientela estaria sempre sujeita a sofrer diminuição, senão extinção, como resultado da própria concorrência lícita, conseqüência inconcebível a um bem jurídico. (LOPES, 2002, p. 44/46)

Saliente-se que a azienda é também denominada de fundo de comércio ou fundo de empresa, configurando o complexo de bens em sentido amplo. E tanto a azienda, quanto o aviamento e a clientela são três aspectos de um só fenômeno econômico-jurídico, qual seja, o empreendimento.

Ademais, no que tange à concorrência desleal, os sujeitos (ativo e passivo) deverão ser, necessariamente, empreendedores econômicos, sejam industriais, comerciantes, prestadores de serviços ou operadores de outras atividades que se ajustem ao conceito econômico jurídico de empreendedor.

Há que se mencionar aqui os atos de concorrência desleal, que podem ser classificados da seguinte forma: a) atos geradores de confusão; b) atos de desvio de clientela; c) atos contrários à moralidade comercial. 
Os atos geradores de confusão são de quem os pratica a obter vantagens da confusão provocada intencionalmente entre empresa e seus produtos, e empresa e produtos de seu competidor, incidindo sobre os signos distintivos de seus concorrentes. Tais atos são os mais frequentes.

Sobre o assunto colacionam-se os seguintes jugados:

EMENTA: APELAÇÃO CÍVEL. OBRIGAÇÃO DE NÃO FAZER. TRANSPORTE COLETIVO DE PASSAGEIROS. CLANDESTINIDADE. PRÁTICA ILEGAL. EMPRESA CONCESSIONÁRIA. INTERESSE PROCESSUAL. PRIMEIRO RECURSO PROVIDO. SEGUNDA APELAÇÃO PREJUDICADA. A empresa concessionária de serviço público de transporte coletivo de passageiros tem interesse processual para propor ação visando impedir a ação de 'perueiros', pois, embora não possa substituir o município na regulamentação e fiscalização do serviço, são elas que sofrem, diretamente, os prejuízos decorrentes da concorrência ilícita e desleal. Primeira apelação provida para cassar a sentença e segundo apelo julgado prejudicado.(APELAÇÃO CÍVEL No 1.0134.08.110092-4/002 - COMARCA DE CARATINGA. Rel. Des. Marcos Lincoln. Data de julgamento: 09-03-2016. Data da publicação: 28-032016)

EMENTA: COMINATÓRIA C/C INDENIZAÇÃO. VENDA DE PRODUTOS CONTRAFEITOS. PRÁTICA ILÍCITA QUE DEVE SER OBSTADA. CONCORRÊNCIA DESLEAL. INDENIZAÇÃO POR DANOS MATERIAIS DEVIDA. CIRCUNSTÂNCIAS DO CASO CONCRETO. DANO MORAL INEXISTENTE.O ato contrário aos usos honestos em matéria industrial ou comercial constitui ato de concorrência desleal, sendo que a simples utilização de denominação, cor e design semelhantes à de outrem, de modo a confundir o consumidor, levando-o a pensar que ambos provêm do mesmo fabricante, de marca conhecida, é suficiente para gerar prejuízos à proprietária da marca. Os lucros cessantes serão determinados pelos critérios do art. 210, da Lei 9.279/96, observadas as circunstâncias do caso concreto. Para que se caracterize o dano moral na pessoa jurídica, é imprescindível que o fato ensejador seja apto a causar efetivo abalo à sua honra objetiva.(APELAÇÃ̃ CÍVEL No 1.0026.13.006315-4/001 - COMARCA DE ANDRADAS. Rel. Des. Pedro Bernardes. Data do julgamento: 06-11-2015. Data da publicação: 20-11-2015)

O desvio de clientela visa denegrir o concorrente e seus produtos e serviços, é o desvio de clientela em proveito próprio. Visa produzir o descrédito do competidor ou de seus produtos.

Os atos contrários à moralidade comercial estão relacionados com a violação de segredo do concorrente, por meio de empregados ou algum integrante da empresa. São os subornos destes visando que divulguem os segredos da empresa, bem como atribuir qualidades que sua empresa não possui.

Oliveira Ascensão, por sua vez, cita mais um tipo de ato de concorrência desleal, qual seja: quanto ao conteúdo, os atos de lesão ao mercado em si, que são aqueles atos que implicam na desorganização do mercado. Comungamos da opinião de Marco Antônio Marcondes Pereira, de que essa espécie deve ser considerada no âmbito institucional da concorrência, uma vez que a desorganização do mercado aflige a livre iniciativa e a livre concorrência. (ASCENSÃO, 1997, p. 95)

No Sistema Jurídico Brasileiro, basta a contrariedade à lei, uma vez que não tem cláusula geral, denominando desleal o ato de empreendedor econômico que, numa concorrência prejudica o competidor, desestabiliza os interesses do Estado e dos consumidores, precisando ser coibido. (MIRANDA, 1983, p. 338)

Revista de Direito Brasileira | São Paulo, SP | v. 14 | n. 6 | p. 215 - 230 | maio/ago. 2016 
Merece análise a função do Direito de Defesa da Concorrência, que é voltado à tutela da livre concorrência, ordenando e dirigindo o mercado.

O objeto da política da concorrência é o bem-estar econômico, que é reduzido pelo abuso do poder de mercado. Não é o monopólio, o lucro do monopólio, o poder de monopólio ou o poder de mercado. Poder de monopólio ou poder de mercado é definido pelo economista como diferença entre o custo marginal e o preço do produto. Pelos investidores antitruste é, na maior parte das vezes, definido como a capacidade da firma de elevar seus preços acima dos custos. Assim, quanto maior o poder de mercado, maior a possibilidade de aumento de preço (supondo sempre custos constantes). Cabe às agências antitruste então, reprimir e prevenir o abuso do poder de mercado. (SANTACRUZ, 2000, p. 2008)

Em um mercado em que há concorrência entre os produtores de um bem ou serviço, os preços praticados tendem a manter-se nos menores níveis possíveis e as empresas precisam buscar constantemente formas de se tornarem mais eficientes para que possam aumentar os seus lucros. À medida que tais ganhos de eficiência são conquistados e difundidos entre os produtores, ocorre uma readequação dos preços, que beneficia o consumidor. Assim, a livre concorrência garante, de um lado, os menores preços para os consumidores e, de outro, o estímulo à criatividade e à inovação das empresas ${ }^{1}$.

Duas formas de práticas concorrenciais ilícitas são reprimidas no Direito Brasileiro: $a$ concorrência desleal e a infração à Ordem Econômica. Nessa seara é fundamental ressaltar a diferença entre ambas. A princípio, nota-se que a infração contra a Ordem Econômica abrange um universo muito maior, uma vez que são milhares e milhares de interesses que podem ser envolvidos, desse modo, a concorrência ilícita ameaça toda a estrutura da economia de mercado, sendo extremamente ampla, constituindo, assim, o plano macrojurídico.

As lesões produzidas pela concorrência desleal não alcançam outros interesses imediatos, a não ser do próprio empresário vitimado pela prática irregular, além de não comprometer as estruturas da livre concorrência como interesse difuso, configurando, assim, o plano microjurídico. Dessa forma a concorrência desleal envolve precipuamente demandante e demandado, enquanto a infração da Ordem Econômica com sua amplitude tem maior para toda a economia.

Nesta seara, destaca Marcelo Gazzi Taddei que a concorrência desleal e a concorrência praticada com abuso do poder econômico, caracterizada como infração à Ordem Econômica, distinguem-se quanto aos pressupostos de caracterização, formas de repressão e tratamento legislativo, além de divergirem em relação ao âmbito dos interesses envolvidos. Não é rara a existência de confusão entre esses diferentes seguimentos do direito concorrencial, sobretudo no que se refere aos interesses protegidos pelos referidos diplomas legais, não obstante as distinções que apresentam conforme exposto na seqüência. A concorrência desleal, disciplinada pela Lei 9.279, de 14.05.1996, denominada pela doutrina como Lei de Propriedade Industrial, envolve os interesses particulares dos empresários concorrentes envolvidos e as lesões produzidas não alcançam de forma imediata outros interesses além dos referentes ao empresário diretamente vitimado pela prática irregular. Os interesses tutelados pela Ordem Econômica são mais abrangentes, visto que as normas de coibição à infração à Ordem Econômica têm por finalidade preservar o livre mercado, alcançando a coletividade. (TADDEI, 2001, p. 26/27)

A confusão entre produtos ou estabelecimento é considerada pela doutrina e presente na jurisprudência como a forma mais comum de concorrência desleal e quem os pratica se propõe a obter vantagens da confusão provocada intencionalmente entre a empresa ou seus produtos, e a

${ }^{1}$ Disponível em www.cade.gov.br Acesso em 27 de abril de 2016.

Revista de Direito Brasileira | São Paulo, SP | v. 14 | n. 6 | p. 215 - 230 | maio/ago. 2016 
empresa ou os produtos de um competidor, geralmente se aproveitando da homonímia ou provocando-a ${ }^{2}$. (REQUIÃO, 2007, p. 356).

Ademais, enquanto a concorrência desleal é reprimida nas searas civil e penal, a infração contra a Ordem Econômica é também reprimida nas searas administrativa e penal.

Nesse contexto Fábio Ulhoa Coelho ainda oferece outra distinção entre esses dois sistemas de concorrência ilícita: a concorrência desleal é sempre ato culposo, enquanto a infração contra a Ordem Econômica independe, para a sua configuração de culpa. De fato, como espécie de abuso de direito que se viabiliza através de meio necessariamente imoral ou desonesto, não existe concorrência desleal sem culpa. Não pode existir. Já a infração à Ordem Econômica independe de tal ingrediente. A análise é objetiva, dos efeitos que determinada conduta provoca - ou poderia provocar - no mercado relevante. (COELHO, 2001, p. 242)

Além disso, no que tange a infração contra a Ordem Econômica é irrelevante o meio empregado. O importante nesse caso são os objetivos do titular do poder econômico e os efeitos de sua prática concorrencial. Portanto, irá depender dos efeitos no caso concreto.

Já para a caracterização da concorrência desleal, não são os objetivos e nem os efeitos e sim o meio empregado que é fundamental. E nesta linha Fábio Ulhoa Coelho elucida: ou o meio, em si considerado, é desonesto, imoral ou condenado pelas práticas usuais dos empresários, e então se configura a concorrência desleal em qualquer situação; ou o meio é honesto, moral e aceito pelas práticas usuais dos empresários, e não se configura esse tipo de ilícito concorrencial, quaisquer que sejam as pessoas, objetivos e efeitos envolvidos. Assente-se, pois, que o ato de concorrência desleal se demonstra pela prova de que o empresário se valeu, na conquista de fatias de mercado, de instrumentos desonestos, imorais e repudiados pela generalidade dos empresários. Já a infração contra a Ordem Econômica, se caracteriza por algumas formas de abuso de posição dominante em determinado segmento de mercado; quais sejam, as práticas empresariais que, por restringirem ou eliminarem a concorrência, ou importarem aumento arbitrário de preços, comprometem a organização liberal da economia. (COELHO, 2001, p. 241)

A proteção contra a concorrência desleal interessa preponderantemente aos comerciantes que sofrem seus efeitos, o que lhe confere um caráter de certa forma particularista, não podendo ser esquecidas, porém, as conseqüências indiretas, que afetam os interesses do mercado como um todo, com o surgimento de desequilíbrio forçado pelo agente, em prejuízo dos demais comerciantes e da clientela em geral. Terão sido tais motivos aqueles em que o legislador firmou a base para a caracterização de certas modalidades de concorrência anormal como crimes. (CAMPOS, 1991, p. 14)

A caracterização da infração da Ordem Econômica é caracterizada pela conjugação de artigos da Lei de Defesa da Concorrência e norma constitucional programadora desta Lei (CF, art. $\left.173, \S 4^{\circ}\right)^{3}$.

João Bosco Leopoldino da Fonseca salienta: a definição do tipo de infração da ordem econômica leva em conta não a estrutura ou a característica do ato, mas o seu objetivo, o seu efeito concreto, independentemente da intenção do agente. $\mathrm{O}$ art. 20 se refere às finalidades concretas, que são atingidas pelos atos praticados pelo agente econômico. São essas finalidades

\footnotetext{
${ }^{2}$ Além da confusão entre produtos ou estabelecimentos tem-se a denigração do concorrente, que visa desviar a clientele, mediante o fomento da depreciação do empresário rival e de seus produtos, bens ou serviços que são colocados à disposição no mercado, com o intuito de prejudicar a reputação de um concorrente ou seu negócio. Tem-se ainda o desrepeito à cláusula contractual, bem como a cláusula de não concorrência, em que o alienante compromete-se a não se estabelecer com o mesmo negócio, em certa área ou em qualquer território, por um período de tempo. Destaca-se também a concorrência parasitária, na qual não se busca a ruína total de seu concorrente, já que para o parasita o importante é que este continue crescendo e inovando em seus produtos, para que possa ter o aproveitamento indevido do sucesso e do esforço empregado, para que posteriormente, possa lançar um produto mais barato e com qualidade inferior.

${ }^{3}$ Quando a atividade empresarial objetiva a destruição de empresas concorrentes, para dominação da clientela e dos mercados e subsequente imposição de preços mais elevados o poder público interfere para combater os excessos do domínio econômico, sendo então infração à ordem econômica. (REQUIÃO, 2007, p. 358).
}

Revista de Direito Brasileira | São Paulo, SP | v. 14 | n. 6 | p. 215 - 230 | maio/ago. 2016 
que identificam tais atos como infrações. Para caracterizar tais atos como infrações contra a ordem econômica, terá o julgador que verificar se eles são concretamente aptos a produzir qualquer dos efeitos, mesmo que estes, na vida econômica real, não sejam alcançados. (FONSECA, 2007, p. 168/169). E os efeitos são os seguintes:

1. lesão da livre concorrência e da livre iniciativa;
2. dominação de mercado relevante de bens ou serviços;
3. situação de lucros arbitrários;
4. exercício abusivo de posição dominante.

Condutas anticompetitivas são quaisquer atos adotados por pessoas físicas e jurídicas que tenham por objeto ou possam produzir os seguintes efeitos, ainda que não sejam alcançados: (i) limitar, falsear ou de qualquer forma prejudicar a livre concorrência ou a livre iniciativa; (ii) dominar mercado relevante de bens ou serviços; (iii) aumentar arbitrariamente os lucros; e (iv) exercer de forma abusiva posição dominante. São exemplos de condutas que podem ser punidas nos termos do art. 36 da Lei ${ }^{\circ}$ 12.529/2011: a fixação de preços ou condições de venda entre concorrentes (cartel), ajustes de preços e condições em licitações públicas (cartel em licitações), discriminação de preços, venda casada, recusa de negociação, prática de preços predatórios e destruição de matérias primas (açambarcamento). É importante ressaltar que a existência de estruturas concentradas de mercado, como monopólios ou oligopólios, em si, não é ilegal do ponto de vista concorrencial. O que ocorre é que nesses casos há maior probabilidade de exercício de poder de mercado e, portanto, maior potencial de ocorrência de condutas anticompetitivas ${ }^{4}$.

Na Lei n. 12.529/2011, a tipificação da infração da ordem econômica manteve-se inalterada, encontrando-se a mesma descrita no caput do art. 36, e seus incisos de I a IV:

Art. 36. Constituem infração da ordem econômica, independentemente de culpa, os atos sob qualquer forma manifestados, que tenham por objeto ou possam produzir os seguintes efeitos, ainda que não sejam alcançados: I - limitar, falsear ou de qualquer forma prejudicar a livre concorrência ou a livre iniciativa; II dominar mercado relevante de bens ou serviços; III - aumentar arbitrariamente os lucros; e IV - exercer de forma abusiva posição dominante.

Ressalte-se que tais atos sujeitarão os infratores de maneira objetiva, vale dizer, independentemente de culpa e, também, independentemente do resultado.

Ato contínuo, seu parágrafo $1^{\circ}$ exclui de punibilidade o chamado monopólio natural em que a conquista de mercado se dá de forma natural fundada na maior eficiência do agente econômico, enquanto, o parágrafo, $2^{\circ}$ determina o que seja posição dominante - como sendo a situação em que uma empresa ou grupo de empresas for capaz de alterar unilateral ou coordenadamente as condições de mercado ou quando controlar $20 \%$ (vinte por cento) ou mais do mercado relevante. $\mathrm{O}$ referido artigo em seu parágrafo $3^{\circ}$, por sua vez, exemplificativamente, enumera as condutas11 que caracterizam infração da Ordem Econômica, sendo de destacar que o art. 119 impede a aplicação da Lei 12.529/2011 aos casos de dumping e subsídios de que tratam os Acordos Relativos à Implementação do Artigo VI do Acordo Geral sobre Tarifas Aduaneiras e Comércio12, promulgados pelos Decretos nos 93.941 e 93.962, de 16 e 22 de janeiro de 1987, respectivamente.

Em caso que restou evidenciada a formação de Cartel entre as empresas e o cometimento de infração à ordem econômica, recentemente decidiu o STJ:

\footnotetext{
${ }^{4}$ Disponível em www.cade.gov.br Acesso em 27 de abril de 2016.
} 
PROCESSUAL CIVIL. ADMINISTRATIVO. COMÉRCIO VAREJISTA DE COMBUSTÍVEIS. PRÁTICA LESIVA. ELIMINAÇÃO DE CONCORRÊNCIA COM POSTOS DE COMBUSTÍVEIS EM HIPERMERCADOS. DEFESA DA LIVRE CONCORRÊNCIA. POSSIBILIDADE. APRECIAÇÃO DO MÉRITO DO ATO ADMINISTRATIVO, CASO HAJA VIOLAÇÃO AO PRINCÍPIO DA LEGALIDADE LATU SENSU E ÀS NORMAS CONSTITUCIONAIS. AUSÊNCIA DE OMISSÃO. ART. 535 DO CPC. INEXISTÊNCIA DE DIVERGÊNCIA JURISPRUDENCIAL. 1. A solução integral da controvérsia, com fundamento suficiente, não caracteriza ofensa ao art. 535 do CPC. 2. A apontada divergência deve ser comprovada, cabendo a quem recorre demonstrar as circunstâncias que identificam ou assemelham os casos confrontados, com indicação da similitude fática e jurídica entre eles. Indispensável a transcrição de trechos do relatório e do voto dos acórdãos recorrido e paradigma, realizando-se o cotejo analítico entre ambos, com o intuito de bem caracterizar a interpretação legal divergente. O desrespeito a esses requisitos legais e regimentais (art. 541, parágrafo único, do $\mathrm{CPC}$ e art. 255 do RI/STJ), como o que se afigura no presente caso, impede o conhecimento do Recurso Especial com base na alínea "c", III, do art. 105 da Constituição Federal. 3. O Tribunal a quo consignou: "A meu convencimento, ainda que a sentença invocasse o princípio da razoabilidade ou proporcionalidade como fundamento de análise dos motivos determinantes da sanção imposta às autoras-apeladas, tal premissa seria descabida aos moldes em que o legislador privativamente atribuiu ao CADE como órgão regulador e fiscalizador da atividade econômica (art. 7o, II, da Lei 8.884/94). Atribuir qualificação diversa a fatos incontroversos - no caso a atuação das autoras e de seu sindicato na repressão à entrada de novo distribuidor no mercado varejista de combustíveis com prejuízo à livre concorrência - é negar o juízo de valor que o legislador incumbiu a um órgão de composição plural e de conhecimentos técnicos sobre a matéria. Estivesse o juiz examinando a vulneração de qualquer outro requisito do ato (competência, finalidade, forma, objeto, motivação), certamente que admissível o controle judicial. No caso concreto, entretanto, o que se viu foi a completa substituição de um juízo valorativo por outro". 4. O Cade atuou os recorrentes pela prática de infração à ordem econômica, porquanto ficou constatado que as empresas não permitiram a entrada de novos distribuidores no mercado varejista de combustíveis. Segundo a autarquia, a rede Gasol e as demais empresas, valendo-se do seu poder econômico, eliminaram a concorrência de postos de combustíveis em estacionamentos de hipermercados. Para tanto, chegaram a exercer pressão em autoridades do Poder Executivo. 5. Após exame acurado dos fatos, o Cade puniu os recorrentes com multa de 5\% do faturamento bruto do ano anterior ao da instauração do procedimento administrativo. A Corte de origem reformou a sentença para restabelecer a punição dada pelo órgão fiscalizador, porquanto não vislumbrou nenhuma ilegalidade no ato administrativo. 6. Em face da constitucionalização do direito administrativo e da evolução do estado de direito, tem-se entendido que o Poder Judiciário pode se imiscuir na análise do mérito do ato administrativo, desde que seja analisado sob o seu aspecto jurídico, e para que sejam observados, além da legalidade em sentido amplo do ato, também os princípios e mandamentos constitucionais. 7. No caso sub judice, constata-se claramente que o magistrado adentrou o mérito do ato administrativo produzido pelo CADE, sem nenhuma justificação de infringência aos ditames da lei ou às normas constitucionais. A fundamentação produzida na sentença para anular a decisão administrativa foi de que a mera pressão e o lobby exercido perante as autoridades públicas não configuram infração à ordem econômica. 8. Depreende-se que a análise 
perpetrada pelo juiz sobre o mérito do ato administrativo não foi jurídica, mas, pelo contrário, casuística, uma verdadeira aventura jurídica, pois não compreendeu os relevantes fatos e provas produzidos pelo CADE, onde ficou evidenciada a formação de Cartel entre as empresas e o cometimento de infração à ordem econômica. 9. Ao contrário do disposto na sentença, o maior prejudicado com a formação do Cartel e o alijamento da livre concorrência no mercado de consumo é o consumidor. Este fica impedido de procurar o melhor preço, tendo que se sujeitar ao valor imposto por aqueles que dominam o mercado de combustíveis no Distrito Federal.10. Agravo Regimental não provido. "(Agravo Regimental não provido. AgRg no REsp 1436903 / DF AGRAVO REGIMENTAL NO RECURSO ESPECIAL 2014/0035705-1. Rel. Herman Benjamin. Data de julgamento: 01-12-2015. Data da publicação: 04-02-2016) (grifou-se)

Observa-se ainda, que a infração à Ordem Econômica atenta contra a regra da livre concorrência. Destarte, ao retratar a Ordem Econômica há que se destacar a livre concorrência, tratando das relações de consumo, da tecnologia e do meio ambiente. Além de novos critérios para a aplicação de multas $-0,1 \%$ a $20 \%$ do faturamento bruto registrado pela empresa, grupo ou conglomerado no ramo de atividade afetado pela conduta anticompetitiva no ano anterior ao início das investigações; outros avanços são identificáveis na processualística da Lei Antitruste Brasileira, como as inovações que ampliam as hipóteses para concessão de leniência 5 .

Em se tratando de livre concorrência complementa Paula Forgioni: assim, no princípio da livre iniciativa (e da livre concorrência) abriga-se, também a atuação estatal no sentido de (i) disciplinar comportamentos que resultariam em prejuízos à concorrência; e (ii) disciplinar a atuação dos agentes econômicos, de forma a implementar uma política pública. Em conclusão, quando a autoridade antitruste autoriza ou coíbe um determinado comportamento do agente econômico, está justamente atuando o princípio da livre iniciativa e da livre concorrência, tal qual modernamente concebidos. (FORGIONI, 1997, p. 54)

Sobre esse assunto complementa Luis Fernando Schuartz que a existência e a manutenção da livre concorrência são abstratamente associadas, para cada gente econômico que participa real ou potencialmente nos processos de troca constitutivos do mercado, a uma margem em princípio indefinida de opções reais e economicamente relevantes de ação criadora, tais como tornar-se agente econômico, celebrar ou não celebrar contratos com $\mathrm{A}, \mathrm{B}$ ou $\mathrm{C}$, produzir ou ofertar produtos ou serviços nestas ou naquelas quantidades, fixar preços, definir estratégias concorrenciais, unir-se com outros agentes na busca de um objetivo comum, incorporar-se a eles, desaparecer como margem etc. Esta margem em princípio definida de opções reais e economicamente relevantes de ação criadora é, num nível bem vago, aquilo que se entende por livre iniciativa. (SCHUARTZ, 1991, p. 70/71)

Dessa forma, há uma relação entre livre iniciativa e livre concorrência.

Quanto às relações de consumo, nota-se que a proteção pelas normas de defesa da concorrência e de defesa do consumidor é necessária para garantir que a economia de mercado continue a se operar efetivamente.

Assim, nota-se que o Direito da Concorrência e o Direito do Consumidor têm o mesmo objetivo, qual seja, facilitar o exercício da soberania do consumidor, efetivando desse modo, seu poder de escolha, atuando de forma imprescindível no Direito Concorrencial.

\footnotetext{
${ }^{5} \mathrm{Na}$ lei anterior (Lei n. ${ }^{\circ} 8.884 / 94$ ), a multa aplicável às empresas variava de $1 \%$ (um por cento) a $30 \%$ (trinta por cento) do valor do faturamento bruto no Brasil do grupo econômico, no seu último exercício. A Lei atual prevê para a empresa multa de $0,1 \%$ (um décimo por cento) a $20 \%$ (vinte por cento) do valor do faturamento bruto da empresa, grupo ou conglomerado obtido, no último exercício anterior à instauração do processo administrativo, no ramo de atividade empresarial em que ocorreu a infração, quando for possível sua estimação.(PEDRA, 2012, p. 06-07)
}

Revista de Direito Brasileira | São Paulo, SP | v. 14 | n. 6 | p. 215 - 230 | maio/ago. 2016 
Em se tratando do Estado em ação na economia, há que salientar a ação-intervenção no plano macrojurídico, em que o Estado atuaria como empresário (CF, arts. 173, 175, 177), usaria da atribuição do poder de polícia (CF, art. 174) visando o bem-estar e ainda faria uso da atribuição de fomento (CF, art. 174), com incentivo e planejamento.

Os princípios básicos a reger a atuação do estado na economia encontram-se nos arts. 173 e 174 da Constituição Federal. De sua leitura depreende-se que três são as funções possíveis do Estado no domínio econômico: em primeiro lugar, como agente direto da atividade econômica; em segundo, como agente fiscalizador do exercício da atividade econômica pelos particulares, e finalmente como agente normativo da atividade econômica. No primeiro caso não há dúvida quanto à sujeição do Estado ao sistema concorrencial. A Constituição de 1988 deixou essa sujeição particularmente clara ao incluir (ao contrário das anteriores) a tradicional proteção contra o abuso do poder econômico em um dos parágrafos que tratam da exploração direta da atividade econômica pelo Estado (art. 173, § $4^{\circ}$ ). A Lei 8.884/94 confirma esse entendimento ao prever a sujeição de todos, sejam pessoas físicas ou jurídicas, de direito público ou privado, às normas concorrenciais. Já, quanto ao poder fiscal e regulamentar, a questão é mais complexa. É necessário verificar a natureza da atividade que está sendo fiscalizada ou normatizada. É a natureza da atividade realizada que determinará a extensão do poder regulamentar e fiscal. Pode o sistema de regulamentação e fiscalização estatal visar ou não à substituição do sistema concorrencial. (SALOMÃ̃ FILHO, 997, p. 36)

Portanto, nota-se que o poder de gestão do Estado é bastante amplo, podendo atuar de forma suplementar na economia, quer fomentando, quer exercendo a atividade econômica, quer ainda intervindo na empresa privada.

A ação-intervenção do Estado no plano microjurídico seria baseada no dirigismo contratual, nos instrumentos processuais de defesa, na tutela penal e civil.

Ressalte-se que há dois institutos repressores da concorrência ilícita no Direito Pátrio: um sistema que é relacionado à tutela da clientela e à propriedade industrial, que visa coibir a deslealdade entre os empresários concorrentes (Lei 9.279/96 - Lei de Propriedade Industrial, art. 209), e um outro sistema relacionado à preservação das estruturas da economia de livre mercado, que tem por objetivo punir as infrações à Ordem Econômica (Lei 12.529/2011 - Lei de Defesa da Concorrência).

Marcelo Gazzi Taddei destaca que no art. 209, a Lei de Propriedade Industrial ressalva ao prejudicado o direito de haver perdas e danos em ressarcimento de prejuízos causados por atos de concorrência desleal não previstos na Lei 9.279/96, tendentes a prejudicar a reputação e os negócios alheios, a criar confusão entre estabelecimentos empresariais ou entre os produtos e serviços colocados no mercado. (TADDEI, 2001, p. 35)

Nesta mesma linha, comenta Fábio Ulhoa Coelho que somente em situações específicas - como na utilização de meios enganosos para promover a oscilação dos preços de concorrente -, ambas as modalidades de concorrência ilícita se configuram. Em geral, o empresário ou queria conquistar a clientela de concorrente ou concorrentes e, para tanto, lançou mão de meios inidôneos (incorrendo em concorrência desleal), ou pretendia valer-se de seu poder econômico para dificultar ou impedir a competição, em prejuízo da "coletividade" (praticando, então, infração da Ordem Econômica). (COELHO, 2002, p. 48)

Portanto, só em caso específico configurar-se-á a ocorrência dos dois institutos repressores da concorrência ilícita. Assim, em raríssimas oportunidades caberá a aplicação simultânea das sanções estabelecidas por esses dois institutos.

João Bosco Leopoldino da Fonseca traçando as perspectivas microeconômica e macroeconômica salienta que o Direito, ao defrontar-se com o fenômeno econômico ocorrente numa sociedade, não pode desconhecer esses diversos direcionamentos. $\mathrm{O}$ legislador, ao elaborar a norma jurídica, tem que levar na devida conta os quadros de atuação da economia. O Direito 
tem uma função direcionadora na economia, não se podendo aceitar a tese materialista do Direito como simples superestrutura. A norma jurídica deve criar o embasamento para o pleno desenvolvimento dos fatores da atividade econômica, podendo influir e direcionar a produção, a circulação, a repartição e o consumo. Mas, ao fazê-lo, será necessário adequar-se aos modelos microeconômico e macroeconômico. (FONSECA, 2007, p. 41)

A Lei n. 12.529/11, consolidou, ainda, os instrumentos de combate a condutas anticompetitivas: permaneceu com lugar reservado a regulação da celebração de Termo de Compromisso de Cessação - TCC de prática anticompetitiva em procedimento preparatório de inquérito administrativo, inquérito e processo administrativo para imposição de sanções administrativas por infrações à ordem econômica. Ademais, a celebração de acordo de leniência com a autoridade antitruste - por intermédio da Superintendência-Geral - continuou contemplada como espécie de "delação premiada" em condutas anticompetitivas. (SILVEIRA, 2013, p. 34)

Insta salientar, que em relação às sanções previstas, houve um abrandamento para as multas aplicáveis em caso de infração da ordem econômica em relação ao regramento anterior, porém, continua a repressão às condutas anticompetitivas.

\section{CONCLUSÃO}

As regras basilares a reger a atuação do Estado na economia encontram-se nos arts. 173 e 174 da Constituição Federal. No plano macrojurídico, o Estado assume o perfil de empresário, com o intuito de corrigir as imperfeições concorrenciais. Atua ainda, através do Poder de Polícia, objetivando o bem-estar social. Ressaltando, que a fiscalização, também chamada de acompanhamento é a própria atuação prévia do Estado, enquanto agente normativo e regulador. $\mathrm{O}$ incentivo nada mais é que o estímulo, o implemento de determinada atividade econômica pelo Estado (benefícios ou vantagens concedidas), incidindo na autonomia dos particulares, guiando-a ao interesse público. Já em relação ao planejamento, se dá quando o Estado atua efetivamente na economia como prestador de serviços. Cabe ao Estado o poder-dever de garantir o equilíbrio da Ordem Econômica e também com a tutela da Lei 12.529/2011.

No plano microjurídico, o Estado interfere no plano privado (Publicização do Estado), através do dirigismo contratual, dos instrumentos processuais de defesa, da tutela penal e civil. Desse modo, a Constituição Federal, em seu art. 173 trata da exploração direta da atividade econômica pelo Estado e em seu art. 174 delineia o papel do Estado como agente normativo e regulador da atividade econômica. É necessário que existam condições estruturais nos mercados, sendo a intervenção do Estado imprescindível. Dessa forma, o exercício da liberdade de iniciativa empresarial tem como pressupostos o respeito à livre concorrência, à função social da propriedade e aos direitos do consumidor.

O plano macrojurídico é a proteção jurídica macroeconômica e o plano microjurídico é a proteção jurídica microeconômica. O macrojurídico próprio do Direito Público, é a tutela da coletividade, interesse difuso; o microjurídico, próprio do Direito Privado é a tutela individual, subjetiva.

A base da organização da defesa da concorrência no plano macrojurídico está na Constituição Federal, art. $1^{\circ}$, inc. IV, art. $5^{\circ}$, incs. XXII e XXIII, art. 170 e na Lei 12.529/2011, que trata da prevenção de infração à Ordem Econômica e repressão ao abuso econômico.

Enquanto a concorrência desleal envolve o particular, a infração à Ordem Econômica envolve o geral, influenciando toda a economia.

Ademais, para a caracterização da concorrência desleal o meio empregado é fundamental, enquanto na infração à Ordem Econômica é irrelevante o meio empregado, e sim os objetivos e os efeitos da prática concorrencial. 
Esses dois institutos de concorrência ilícita devem ser combatidos não apenas pelos concorrentes lesados, como por toda a sociedade; afinal, a defesa da concorrência deve configurar um instrumento para um mercado transparente, saudável e leal, tornando viável o equilíbrio entre liberdade e proteção.

À guisa de concluir, evidenciou-se que a Lei 12.529/2011, conforme o Princípio Constitucional da Livre Concorrência deve ser visualizada sob a perspectiva capaz de otimizar a alocação dos diversos fatores produtivos, segundo o ambiente institucional do livre mercado, que deve ser administrativamente regulado, propiciando o desenvolvimento do país, afinal, o mercado competitivo é um bem jurídico que pertence a toda coletividade.

\section{REFERÊNCIAS}

ASCENSÃO, J. de O. Concorrência desleal. Coimbra: Almedina, 1997.

BARBIERI FILHO, C. Disciplina jurídica da concorrência: abuso do poder econômico. São Paulo: Resenha Tributária, 1984.

BITTAR, Carlos Alberto. Teoria e Prática da Concorrência Desleal. São Paulo: Forense Universitária, 2005.

BLACK, H. C. Black's law dictionary. St. Paul: West Publishing Co., 1979.

CARVALHOSA, M. Direito econômico. São Paulo: Revista dos Tribunais, 1973.

CARVAlHOSA, M. S. B. Poder econômico: a fenomenologia - seu disciplinamento jurídico. São Paulo: Revista dos Tribunais, 1967.

COELHO, F. U. Curso de Direito Comercial: de acordo com o novo Código Civil e alterações da LSA. 6. ed. São Paulo: Saraiva, 2002. v 1.

DANNESMANN, et al. Comentários à lei de propriedade industrial e correlatos. Rio de Janeiro: Renovar, 2001.

DANTAS, I. Direito constitucional econômico: globalização \& constitucionalismo. Curitiba: Juruá, 1999.

DINIZ, M. H. Dicionário jurídico. São Paulo: Saraiva, 1998.

FARIA, W. Direito de concorrência e contrato de distribuição. Porto Alegre: Sérgio Antônio Fabris, 1992.

FARJAT, G. A noção do direito econômico. Tradução de Leopoldino da Fonseca. Belo Horizonte: Movimento Editorial da Faculdade de Direito da UFMG, 1996.

FONSECA, J. B. L. Direito econômico. Rio de Janeiro: Forense, 2008.

Lei de proteção à concorrência - comentários à Lei Antitruste. Rio de Janeiro: Forense, 1995. 
FONSECA, J. J. B. da. Direito antitruste e o regime das concentrações empresariais. São Paulo: Atlas, 1995. p. 29.

GLÓRIA, D. F. de A. A livre concorrência como garantia do consumidor. Belo Horizonte: Del Rey, 2003.

MIRANDA, P. Tratado de direito privado. XVII. 4. ed. São Paulo: Revista dos Tribunais, 1983. n. 1, v. 7.

PEDRA, D. P. A Nova Lei de Defesa da Concorrência Brasileira - Principais Modificações e Impactos para as Agências Reguladoras. www.egov.ufsc.br Publicado em 22 de maio de 2012. Acesso em 27 de abril de 2016.

PEREIRA, M. A. M. Concorrência desleal por meio da publicidade. São Paulo: Juarez de Oliveira, 2001.

REQUIÃO, Rubens. Curso de Direito Comercial. 27 ed. São Paulo: Saraiva, 2008. 1 v.

SANTACRUZ, R. Política antitruste no Brasil: a atuação do Cade. Revista Arche'typon. Rio de Janeiro, a. 8, n. 22, p. 8, jan./abr. 2000.

SCHUARTZ, L. F. Dogmática jurídica e Lei 8.884/94. Revista de Direito Mercantil, Industrial, Econômico e Financeiro. São Paulo, a. XXXVI (Nova Série), n. 107, jul./set. 1997.

SHIEBER, B. M. Abusos do poder econômico: direito e experiência antitruste no Brasil e nos EUA. São Paulo: Revista dos Tribunais, 1996.

SILVEIRA, B. S. A nova lei de defesa da concorrência : desafio da análise prévia dos atos de concentração. ano 2, v. 01, n. 03, Revista RedGV, São Paulo, julho 2013.p. 26-38.

SODRÉ FILHO, A. C. de A.; ZACLIS, L. Comentários à legislação antitruste: direito econômico. Defesa da Livre Concorrência. São Paulo: Atlas, 1992.

SOUZA, W. P. A. de. Primeiras linhas de direito econômico. 3. ed. São Paulo: LTr, 1994.

TADDEI, M. G. O dumping e as normas internas de proteção à concorrência empresarial. Franca: FHDSS, 2001. 234 f. Dissertação (Mestrado em Direito) - Faculdade de História, Direito e Serviço Social da Universidade Estadual Paulista Júlio de Mesquita Filho, 2001.

TAVARES, A. R. Direito constitucional econômico. São Paulo: Método, 2003.

VAZ, I. Direito econômico da concorrência. Rio de Janeiro: Forense, 1993 